\title{
Comparison of methodologies to determine the apparent ileal amino acid digestibility of maize, wheat, lupins, and peas for broiler chickens
}

\author{
C.L. Nalle ${ }^{1,2}$ and V. Ravindran ${ }^{1^{*}}$ \\ ${ }^{1}$ Monogastric Research Centre, School of Agriculture and Environment, Massey University, Palmerston North 4442, \\ New Zealand; ${ }^{2}$ Present address: Department of Animal Husbandry, Kupang State Agriculture Polytechnic, Kupang 85228, \\ Nusa Tennara Timur, Indonesia; v.ravindran@massey.ac.nz
}

Received: 17 May 2021 / Accepted: 1 July 2021

(c) 2021 C.L. Nalle and V. Ravindran

RESEARCH ARTICLE POULTRY

\begin{abstract}
The influence of method (direct vs difference method) used to determine the apparent ileal digestibility coefficient (AIDC) of amino acids in two cereals (maize and wheat) and two grain legumes (Australian sweet lupins and peas) was investigated. For the direct method, the test ingredients were incorporated as the sole source of protein in assay diets. The assay diets used in the difference method were formulated by substituting the cereals and legumes for 50 and 25\% (w/w), respectively, of a maize-soy basal diet. Each diet contained $3 \mathrm{~g} / \mathrm{kg}$ titanium dioxide as an indigestible marker and were offered ad libitum to four replicate cages of broilers (four birds/cage) from d 28 to d 35 post-hatching. On d 35, digesta were collected from the terminal ileum and the AIDC of amino acids were calculated using marker ratios in the diet and digesta. Except for histidine, methionine, cysteine and tyrosine, the main effect of methods was found to be significant $(P<0.05$ to 0.001$)$ for the AIDC of all amino acids. The main effect of the ingredients was significant $(P<0.05$ to 0.001$)$ for all amino acids, except for histidine, aspartic acid and serine. Interactions $(P<0.05)$ between ingredients and method were observed only for leucine, lysine, proline and serine. The AIDC of amino acids, determined by the difference method, was found to be distinctly higher than those determined by the direct method. This suggested that the direct method underestimated amino acid digestibility in low and medium protein ingredients.
\end{abstract}

Keywords: amino acids, assay methods, broilers, digestibility

\section{Introduction}

Published data on the apparent ileal digestibility coefficient (AIDC) of amino acids from feed ingredients for poultry show large differences and even in samples within the same feedstuffs (Bryden et al., 2009). In addition to inherent ingredient- and bird-related factors, this variability is associated with methodological differences, including assay diets, choice of digesta markers, method of euthanasia, site of digesta collection and assay methodology (Ravindran et al., 2017).

Three different methods, namely, the direct, difference and regression, have been used to determine the amino acid digestibility of feed ingredients for poultry (Lemme et al., 2004). The direct method is most commonly used to measure amino acid digestibility in feed ingredients, largely because of the simplicity of the assay diet and calculations (Ravindran and Bryden, 1999). In this method, the test ingredient represents the sole source of amino acids in a dextrose or starch-based assay diet, fortified with minerals and vitamins. The digestibility calculations assume that the amino acid digestibility of the diet is representative of that of the feed ingredient. However, this assumption is not always true and can lead to some errors in calculations because the diet itself triggers the secretion of endogenous amino acids. In addition, this error will be exacerbated as the amino acid concentration in the test diet decreases (Lemme et al., 2004) 
In the difference method, the test diet comprises a mixture of basal and test ingredients (Lemme et al., 2004). The digestibility in the test ingredient is calculated using the difference between the basal and test diets, and the contribution level of the amino acids in the test diet. It is assumed that there is no interaction between the basal diet and the test ingredient. The regression method has been used in some studies, but is not popular because of the cost involved.

The aim of the present study was to examine the influence of method of determination (direct vs difference) on the AIDC of amino acids in two cereals (maize and wheat) and two grain legumes (Australian sweet lupins and peas) for broilers.

\section{Materials and methods}

\section{Ingredients}

Two cereals (maize and wheat) and two grain legumes (Australian sweet lupins Lupinus angustifolius and field peas Pisum sativum) were used. Wheat and maize are low in protein, and peas and Australian sweet lupins have moderate protein levels. The cereals and legume seeds, with hulls, were ground to pass through a $3-\mathrm{mm}$ sieve in a hammer mill prior to the inclusion into assay diets.

\section{Birds and housing}

Day-old male broilers (Ross 308), obtained from a commercial hatchery, were raised in floor pens, and fed a commercial broiler starter diet ( $230 \mathrm{~g} / \mathrm{kg}$ crude protein) until $21 \mathrm{~d}$ of age. Feed and water were freely available. The temperature was maintained at $32{ }^{\circ} \mathrm{C}$ during the first week and gradually decreased to $23^{\circ} \mathrm{C}$ by the third week of age. Ventilation was controlled by a central ceiling extraction fan and wall inlet ducts. On d 21, 128 birds of uniform body weight were selected and randomly assigned to 32 cages (four birds per cage). The birds were offered a commercial broiler finisher diet (180 g/kg crude protein) until the introduction of assay diets on $\mathrm{d} 28$, when four replicate cages were randomly assigned to each assay diet.

\section{Diets}

A total of eight treatment diets representing four feed ingredients were assayed. In the direct method, the test ingredients were incorporated as the sole source of protein in the diet (Table 1). For cereals, diets contained $938 \mathrm{~g} / \mathrm{kg}$ of test cereal, $20 \mathrm{~g}$ of vegetable oil and $39 \mathrm{~g}$ of mineral and vitamin supplements. For protein meals, assay diets were based on dextrose (dextrose monohydrate starch; Australasia Ltd, Tamworth, NSW, Australia) and the test ingredient. The proportion of dextrose and the test protein was varied such that $180 \mathrm{~g}$ crude protein $/ \mathrm{kg}$ feed was
Table 1. Composition (g/kg air dry basis) of assay diets - direct method.

$\begin{array}{lcccc}\text { Ingredient } & \text { Maize } & \text { Wheat } & \text { Lupin } & \text { Peas } \\ \text { Test ingredient } & 938 & 938 & 450 & 720 \\ \text { Dextrose } & - & - & 451 & 181 \\ \text { Soybean oil } & 20 & 20 & 60 & 60 \\ \text { Sodium bicarbonate } & 2 & 2 & 2 & 2 \\ \text { Dicalcium phosphate } & 19 & 19 & 19 & 19 \\ \text { Limestone } & 13 & 13 & 10 & 10 \\ \text { Salt } & 2.0 & 2.0 & 2.0 & 2.0 \\ \text { Trace mineral-vitamin premix } & 3.0 & 3.0 & 3.0 & 3.0 \\ \text { Titanium dioxide } & 3 & 3 & 3 & 3\end{array}$

1 Provided per kg diet: Co, 0.3 mg; Cu, 5 mg; Fe, 25 mg; I, 1 mg; Mn, 125 mg; Zn, $60 \mathrm{mg}$; choline chloride, $638 \mathrm{mg}$; trans-retinol, $3.33 \mathrm{mg}$; cholecalciferol, $60 \mu \mathrm{g}$; dl-a-tocopheryl acetate, $60 \mathrm{mg}$; menadione, $4 \mathrm{mg}$; thiamin, $3.0 \mathrm{mg}$; riboflavin, $12 \mathrm{mg}$; niacin, $35 \mathrm{mg}$; calcium panthothenate, $12.8 \mathrm{mg}$; pyridoxine, $10 \mathrm{mg}$; cyanocobalalamin, $0.017 \mathrm{mg}$; folic acid $5.2 \mathrm{mg}$; biotin, $0.2 \mathrm{mg}$; antioxidant, $100 \mathrm{mg}$; molybdenum, $0.5 \mathrm{mg}$; selenium, $200 \mu \mathrm{g}$.

provided in each assay diet. The assay diets had identical calcium and phosphorus levels.

In the difference method, the assay diets were formulated by substituting the cereal and grain legume for 50 and $25 \%$ (w/w), respectively, of a maize-soy basal diet (Table 2). Titanium dioxide was added at $3 \mathrm{~g} / \mathrm{kg}$ to all experimental diets as an indigestible marker to calculate the AIDC.

\section{Digestibility assay procedures}

On d 35 of age, the birds were euthanised by an intracardial injection of sodium pentobarbitone $(1 \mathrm{ml}$ per $2 \mathrm{~kg}$ live weight), and digesta in the lower half of the ileum were collected by gently flushing with distilled water into plastic containers and pooled within each cage. The ileum was defined as the portion of the small intestine extending from the vitelline diverticulum to a point $40 \mathrm{~mm}$ proximal to the ileo-caecal junction. The digesta samples were frozen at

Table 2. Composition of the maize-soybean basal diets used in the difference method.

$\begin{array}{lc}\text { Ingredient } & \text { g/kg air dry basis } \\ \text { Maize } & 595 \\ \text { Soybean meal } & 352 \\ \text { Soybean oil } & 18 \\ \text { Dicalcium phosphate } & 22 \\ \text { Limestone } & 7.8 \\ \text { Salt } & 2.0 \\ \text { Sodium bicarbonate } & 2.3 \\ \text { Trace mineral-vitamin premix } & 3.0\end{array}$

1 Provided per kg diet: Co, 0.3 mg; Cu, 5 mg; Fe, 25 mg; I, 1 mg; Mn, 125 mg; $\mathrm{Zn}, 60 \mathrm{mg}$; choline chloride, $638 \mathrm{mg}$; trans-retinol, $3.33 \mathrm{mg}$; cholecalciferol, $60 \mu \mathrm{g}$; dl-a-tocopheryl acetate, $60 \mathrm{mg}$; menadione, $4 \mathrm{mg}$; thiamin, $3.0 \mathrm{mg}$; riboflavin, $12 \mathrm{mg}$; niacin, $35 \mathrm{mg}$; calcium panthothenate, $12.8 \mathrm{mg}$; pyridoxine, $10 \mathrm{mg}$; cyanocobalalamin, $0.017 \mathrm{mg}$; folic acid $5.2 \mathrm{mg}$; biotin, $0.2 \mathrm{mg}$; antioxidant, $100 \mathrm{mg}$; molybdenum, $0.5 \mathrm{mg}$; selenium, $200 \mu \mathrm{g}$. 
$-20{ }^{\circ} \mathrm{C}$ in airtight containers immediately after collection and subsequently freeze-dried. The digesta samples, as well as samples of ingredients and diets, were ground to pass through $0.5 \mathrm{~mm}$ sieve and stored in airtight plastic containers. The diet and digesta samples were analysed for dry matter, titanium oxide and amino acids, while ingredient samples were analysed for dry matter and amino acids.

\section{Chemical analysis}

Standard AOAC (2016) methods were used for proximate analysis. Dry matter was determined using method 930.15; ash by method 942.05 , using a muffle furnace at $550{ }^{\circ} \mathrm{C}$ for $16 \mathrm{~h}$. Nitrogen was determined by the method of Sweeney (1989) using a FP-428 nitrogen determinator (LECO ${ }^{\circledR}$ Corporation, St Joseph, MI, USA). The crude protein concentration was calculated as $\mathrm{N} \times 6.25$. Crude fat was determined by Soxtec extraction procedure (method 2003.06; AOAC, 2016) using the Soxtec System (HT 1043 Extraction Unit, Höganäs, Sweden). Neutral detergent fibre (method 2002.04; AOAC, 2016) was determined using Tecator Fibertec ${ }^{\mathrm{TM}}$ equipment (FOSS, Hilleroed, Denmark). Amino acid concentrations were determined by high-performance liquid chromatography, as described by Ravindran et al. (2009). Titanium oxide was measured using the method described by Short et al. (1996).

\section{Calculations}

The apparent ileal digestibility coefficient (AIDC) of amino acids was calculated for both the direct and difference methods, as shown below:

Direct method:

$$
\text { AIDC }=\frac{\left(\frac{\mathrm{AA}}{\mathrm{Ti}}\right)_{\text {diet }}-\left(\frac{\mathrm{AA}}{\mathrm{Ti}}\right)_{\text {ileal }}}{\left(\frac{\mathrm{AA}}{\mathrm{Ti}}\right)_{\text {diet }}}
$$

where,

$(\mathrm{AA} / \mathrm{Ti})_{\text {diet }}=$ ratio of amino acid to titanium in diet, and $(\mathrm{AA} / \mathrm{Ti})_{\text {ileal }}=$ ratio of amino acid to titanium in ileal digesta .

Difference method:

The AIDC of AA in the basal and assay diets and the ingredients were calculated as shown below (Nalle et al., 2011a).

$$
\text { AIDC of diet }=\frac{\left(\frac{\mathrm{AA}}{\mathrm{Ti}}\right)_{\text {diet }}-\left(\frac{\mathrm{AA}}{\mathrm{Ti}}\right)_{\text {ileal }}}{\left(\frac{\mathrm{AA}}{\mathrm{Ti}}\right)_{\text {diet }}}
$$

where, $(\mathrm{AA} / \mathrm{Ti})_{\text {diet }}=$ ratio of amino acid to titanium in diet, and $(\mathrm{AA} / \mathrm{Ti})_{\text {ileal }}=$ ratio of amino acid to titanium in ileal digesta.
AIDC of cereal $=$

(AIDC of cereal diet $\times$ AA of cereal diet) $-($ AIDC of basal diet $\times$ AA of basal diet $\times 0.50$ )

$$
(0.50 \times \text { AA of cereal })
$$

AIDC of legume

(AIDC of legume diet $\times$ AA of legume diet) $-($ AIDC of basal diet $\times$ AA of basal diet $\times 0.75$ ) $(0.25 \times$ AA of legume $)$

\section{Statistical analysis}

The data were analysed by two-way analysis of variance using the General Linear Model procedure of SAS (SAS Institute, 2005). Differences were considered significant at $P<0.05$ and significant differences between means were separated by the least significant difference test.

\section{Results}

\section{Proximate and amino acid concentrations}

The analysed proximate composition and amino acid concentrations in the two cereals (maize and wheat) and two legumes (Australian sweet lupins and peas) are summarised in Table 3. In the cereals, leucine and glutamic acid were the most prominent indispensable and dispensable amino acids, respectively. In the legumes, arginine and aspartic acid were the most abundant indispensable and dispensable amino acid, respectively. The most limiting indispensable amino acids observed in both in sources was methionine, followed by cysteine. As expected, in line with higher protein concentrations, amino acid concentrations were markedly higher in the legume sources.

Table 3. Concentration of proximate components and amino acids in test ingredients.

$\begin{array}{lcccc}\text { Proximate composition g/kg } & \text { Maize } & \text { Wheat } & \text { Lupin } & \text { Peas } \\ \text { Dry matter } & 920 & 906 & 915 & 905 \\ \text { Crude protein } & 94.6 & 136 & 286 & 242 \\ \text { Ether extract } & 33.5 & 20.6 & 62.1 & 22.1 \\ \text { NDF } & 86.0 & 108 & 305 & 230 \\ \text { Ash } & 22.5 & 18.9 & 42.0 & 30.5 \\ \text { Amino acids } & & & & \\ \text { Indispensable } & & & & \\ \text { Arginine } & 4.39 & 6.55 & 31.8 & 22.0 \\ \text { Histidine } & 2.92 & 3.29 & 8.51 & 6.46 \\ \text { Isoleucine } & 3.25 & 4.16 & 11.0 & 9.68 \\ \text { Leucine } & 11.4 & 8.90 & 19.2 & 17.5 \\ \text { Lysine } & 2.93 & 3.81 & 15.4 & 17.3 \\ \text { Methionine } & 2.04 & 2.32 & 2.55 & 2.59 \\ \text { Phenylalanine } & 4.76 & 6.45 & 10.4 & 10.9 \\ \text { Threonine } & 3.28 & 3.91 & 12.5 & 8.97 \\ \text { Valine } & 4.35 & 5.95 & 11.5 & 10.5 \\ \text { Dispensable } & & & & \\ \text { Alanine } & 6.82 & 5.14 & 11.1 & 10.0 \\ \text { Aspartic acid } & 6.58 & 8.03 & 27.2 & 28.6 \\ \text { Cysteine } & 1.85 & 2.60 & 5.48 & 3.10 \\ \text { Glycine } & 3.59 & 5.78 & 11.8 & 10.4 \\ \text { Glutamic acid } & 18.2 & 42.0 & 59.3 & 39.6 \\ \text { Proline } & 9.42 & 12.86 & 9.88 & 9.61 \\ \text { Serine } & 3.93 & 5.63 & 10.9 & 10.3 \\ \text { Tyrosine } & 3.62 & 4.55 & 9.66 & 8.30 \\ & & & & \end{array}$




\section{Apparent ileal amino acid digestibility}

Significant method $\times$ ingredient interactions $(P<0.05$ to 0.001 ) between ingredients and methods were found for leucine, lysine, serine, and proline (Tables 4 and 5). The AIDC of leucine in sweet lupins, determined with the difference method, was higher $(P<0.05)$ than the direct method. Lysine digestibility in maize and wheat determined with the difference method was markedly higher $(P<0.05)$ than the direct method. The digestibility coefficients of proline and serine in sweet lupins and peas determined with the difference method was higher $(P<0.05)$ than those determined with the direct method.

The main effect of method was found to be significant $(P<0.01$ to 0.001$)$ for the AIDC of most amino acids (Table 5). Except for histidine, methionine, cystine and tyrosine, the AIDC of amino acids determined using the difference method was higher $(P<0.05)$ than the direct method.

The main effect of ingredients was significant $(P<0.05$ to $P<0.001)$ for AIDC of all amino acids, except for histidine, aspartic acid, and serine (Table 5). The AIDC of methionine and phenylalanine of the cereals were higher $(P<0.05)$ than grain legumes. The AIDC of threonine in grain legumes was higher $(P<0.05)$ than in cereals. Lysine digestibility in maize was similar $(P>0.05)$ to peas and sweet lupins, and higher $(P<0.05)$ than in wheat.
The average AIDC of indispensable amino acids in maize was higher $(P<0.05)$ than in wheat, Australian sweet lupin and or. In the case of dispensable amino acids, the average AIDC of amino acids in cereals and lupins was similar $(P>0.05)$. No difference $(P>0.05)$ was found for overall average AIDC of amino acids among the four ingredients.

\section{Discussion}

The proximate and amino acid concentrations of test ingredients are, in general, within the range reported in the literature (Bryden et al., 2009; Gatel, 1994; Nalle, 2009; NRC, 2012; Petterson et al., 1997). Some variation in ingredient nutrient composition was expected due to differences in cultivar, geographical location, agronomy, growing season, and analytical techniques (Mateos et al., 2019).

Most of the available published data on digestible amino acids in feed ingredients for broilers has been derived using the direct method. The AIDC of amino acids in wheat, maize, lupins and peas obtained by the direct method in the current study were consistent with previous published data (Bryden et al., 2009; Huang et al., 2006, 2007; Ravindran et al., 2005). The difference method has been used in limited number of studies such as Nalle et al. (2011a,b), who reported the AIDC of amino acids in peas and sweet lupins. Their results compared well with those reported in the current study.

Table 4. Influence of methodology on the apparent ileal digestibility coefficient in test ingredients for broilers ${ }^{1,2}$

\begin{tabular}{|c|c|c|c|c|c|c|c|c|c|}
\hline \multirow[t]{3}{*}{ Amino acid } & \multicolumn{8}{|c|}{ Ingredient } & \multirow[t]{3}{*}{ Pooled SEM } \\
\hline & \multicolumn{2}{|l|}{ Maize } & \multicolumn{2}{|l|}{ Wheat } & \multicolumn{2}{|l|}{ Lupin } & \multicolumn{2}{|l|}{ Peas } & \\
\hline & Dir & Diff & Dir & Diff & Dir & Diff & Dir & Diff & \\
\hline \multicolumn{10}{|l|}{ Indispensable } \\
\hline Arginine & 0.868 & 0.965 & 0.774 & 0.857 & 0.900 & 0.949 & 0.888 & 0.920 & 0.014 \\
\hline Histidine & 0.807 & 0.800 & 0.764 & 0.816 & 0.755 & 0.797 & 0.784 & 0.774 & 0.023 \\
\hline Isoleucine & 0.839 & 0.908 & 0.821 & 0.886 & 0.784 & 0.863 & 0.788 & 0.846 & 0.015 \\
\hline Leucine & $0.898^{a}$ & $0.902^{\mathrm{a}}$ & $0.842^{b c}$ & $0.883^{a b}$ & $0.798^{\mathrm{C}}$ & $0.905^{a}$ & $0.803^{c}$ & $0.844^{b c}$ & 0.016 \\
\hline Lysine & $0.805^{d}$ & $0.930^{\mathrm{a}}$ & $0.750^{e}$ & $0.852^{b c}$ & $0.831^{\mathrm{cd}}$ & $0.857^{b c}$ & $0.863^{b c}$ & $0.891^{a b}$ & 0.014 \\
\hline Methionine & 0.893 & 0.896 & 0.859 & 0.883 & 0.787 & 0.741 & 0.785 & 0.826 & 0.025 \\
\hline Phenylalanine & 0.900 & 0.947 & 0.893 & 0.942 & 0.817 & 0.919 & 0.821 & 0.865 & 0.016 \\
\hline Threonine & 0.693 & 0.699 & 0.697 & 0.747 & 0.765 & 0.819 & 0.746 & 0.782 & 0.016 \\
\hline Valine & 0.830 & 0.874 & 0.804 & 0.858 & 0.764 & 0.840 & 0.774 & 0.837 & 0.015 \\
\hline Mean & 0.837 & 0.880 & 0.801 & 0.858 & 0.800 & 0.854 & 0.806 & 0.843 & 0.013 \\
\hline \multicolumn{10}{|l|}{ Dispensable } \\
\hline Alanine & 0.883 & 0.892 & 0.765 & 0.810 & 0.790 & 0.847 & 0.791 & 0.840 & 0.015 \\
\hline Aspartic acid & 0.803 & 0.876 & 0.762 & 0.860 & 0.782 & 0.834 & 0.813 & 0.846 & 0.016 \\
\hline Cysteine & 0.745 & 0.721 & 0.811 & 0.791 & 0.790 & 0.844 & 0.605 & 0.612 & 0.029 \\
\hline Glycine & 0.772 & 0.820 & 0.773 & 0.829 & 0.784 & 0.834 & 0.796 & 0.812 & 0.016 \\
\hline Glutamic acid & 0.898 & 0.935 & 0.931 & 0.953 & 0.869 & 0.923 & 0.858 & 0.911 & 0.014 \\
\hline Proline & $0.883^{a}$ & $0.846^{a}$ & $0.914^{a}$ & $0.913^{a}$ & $0.733^{b}$ & $0.873^{a}$ & $0.770^{b}$ & $0.847^{a}$ & 0.024 \\
\hline Serine & $0.775^{\mathrm{cd}}$ & $0.798^{b c d}$ & $0.789^{b c d}$ & $0.829^{a b}$ & $0.717^{e}$ & $0.862^{\mathrm{a}}$ & $0.756^{\text {de }}$ & $0.813^{b c}$ & 0.017 \\
\hline Tyrosine & 0.866 & 0.854 & 0.854 & 0.871 & 0.814 & 0.863 & 0.812 & 0.827 & 0.015 \\
\hline Mean & 0.828 & 0.843 & 0.825 & 0.857 & 0.785 & 0.860 & 0.775 & 0.813 & 0.014 \\
\hline Overall mean ${ }^{3}$ & 0.833 & 0.862 & 0.812 & 0.858 & 0.793 & 0.857 & 0.791 & 0.829 & 0.013 \\
\hline
\end{tabular}

${ }^{1}$ Each value represents mean of four replicates.

2 Values in the same row with different superscripts are significantly different $(P<0.05)$.

${ }^{3}$ Average digestibility of 17 amino acids. 
Table 5. Influence of methodology on the apparent ileal digestibility coefficient in test ingredients for broilers - main effects. ${ }^{1,2,3}$

\begin{tabular}{|c|c|c|c|c|c|c|c|c|c|}
\hline \multirow[t]{3}{*}{ Amino acid } & \multicolumn{6}{|c|}{ Main effects } & \multicolumn{3}{|c|}{ Probability, $P$} \\
\hline & \multicolumn{4}{|c|}{ Ingredient (I) } & \multicolumn{2}{|c|}{ Method (M) } & \multirow[b]{2}{*}{ I } & \multirow[b]{2}{*}{ M } & \multirow[b]{2}{*}{$I \times M$} \\
\hline & Maize & Wheat & Lupin & Peas & Dir & Diff & & & \\
\hline \multicolumn{10}{|l|}{ Indispensable } \\
\hline Arginine & $0.916^{a}$ & $0.816^{b}$ & $0.925^{a}$ & $0.904^{a}$ & $0.858^{b}$ & $0.923^{a}$ & $* \star *$ & $* * *$ & NS \\
\hline Histidine & 0.803 & 0.790 & 0.776 & 0.779 & 0.777 & 0.797 & NS & NS & NS \\
\hline Isoleucine & $0.874^{a}$ & $0.854^{a b}$ & $0.823^{b c}$ & $0.817^{c}$ & $0.808^{b}$ & $0.876^{a}$ & $* *$ & $* * *$ & NS \\
\hline Leucine & 0.900 & 0.862 & 0.851 & 0.823 & 0.835 & 0.883 & $* *$ & $* * *$ & * \\
\hline Lysine & 0.867 & 0.801 & 0.844 & 0.877 & 0.812 & 0.883 & $* \star \star$ & $* * *$ & $* *$ \\
\hline Methionine & $0.895^{a}$ & $0.871^{a}$ & $0.764^{b}$ & $0.806^{b}$ & 0.831 & 0.837 & $\star \star \star *$ & NS & NS \\
\hline Phenylalanine & $0.923^{a}$ & $0.918^{a}$ & $0.868^{b}$ & $0.843^{b}$ & $0.858^{b}$ & $0.918^{a}$ & $* * *$ & $* * *$ & NS \\
\hline Threonine & $0.696^{b}$ & $0.722^{b}$ & $0.792^{\mathrm{a}}$ & $0.764^{a}$ & $0.725^{b}$ & $0.762^{a}$ & $* * *$ & $* *$ & NS \\
\hline Valine & $0.852^{\mathrm{a}}$ & $0.831^{a b}$ & $0.802^{b}$ & $0.805^{b}$ & $0.793^{b}$ & $0.852^{\mathrm{a}}$ & $* *$ & $* * *$ & NS \\
\hline Mean & $0.859^{a}$ & $0.830^{b}$ & $0.828^{b}$ & $0.824^{b}$ & $0.811^{b}$ & $0.859^{a}$ & NS & $* * *$ & NS \\
\hline \multicolumn{10}{|l|}{ Dispensable } \\
\hline Alanine & $0.888^{a}$ & $0.788^{b}$ & $0.818^{b}$ & $0.815^{b}$ & $0.807^{b}$ & $0.847^{a}$ & $* * *$ & $* *$ & NS \\
\hline Aspartic acid & 0.839 & 0.810 & 0.808 & 0.829 & $0.790^{b}$ & $0.854^{a}$ & NS & $\star * \star *$ & NS \\
\hline Cysteine & $0.733^{b}$ & $0.801^{a}$ & $0.817^{a}$ & $0.609^{c}$ & 0.738 & 0.742 & $* \star *$ & NS & NS \\
\hline Glycine & 0.796 & 0.801 & 0.809 & 0.804 & $0.781^{b}$ & $0.824^{a}$ & NS & $* *$ & NS \\
\hline Glutamic acid & $0.916^{b}$ & $0.942^{\mathrm{a}}$ & $0.896^{b c}$ & $0.804^{c}$ & $0.889^{b}$ & $0.931^{a}$ & $* *$ & $* * *$ & NS \\
\hline Proline & 0.865 & 0.913 & 0.803 & 0.809 & 0.825 & 0.869 & $* * *$ & $* *$ & $* *$ \\
\hline Serine & 0.787 & 0.809 & 0.789 & 0.784 & 0.759 & 0.825 & NS & $* * *$ & ** \\
\hline Tyrosine & $0.860^{a}$ & $0.863^{a}$ & $0.839^{a b}$ & $0.819^{b}$ & 0.837 & 0.854 & * & NS & NS \\
\hline Mean & $0.835^{a}$ & $0.841^{a}$ & $0.822^{a b}$ & $0.794^{b}$ & $0.803^{b}$ & $0.843^{a}$ & * & $* * *$ & NS \\
\hline Overall mean 4 & 0.848 & 0.835 & 0.825 & 0.810 & $0.807^{b}$ & $0.851^{a}$ & NS & $\star * \star *$ & NS \\
\hline
\end{tabular}

1 Each value represents mean of four replicates.

2 * $P<0.05 ;{ }^{* *} P<0.01 ; * \star * x<0.001 ;$ NS $P>0.05$.

${ }^{3}$ Values in the same row with different superscripts are significantly different $(P<0.05)$.

${ }^{4}$ Average digestibility of 17 amino acids.

The current data demonstrated that the AIDC of most amino acids in the test ingredients determined by the direct method was considerably lower than those from the difference method. Similar findings have been reported in pigs by Fan and Sauer (1995a), who determined the AIDC of amino acids in barley (a low-protein ingredient at $114 \mathrm{~g} / \mathrm{kg}$ crude protein) and reported that the digestibility was underestimated by the direct method. In contrast, Fan and Sauer (1995b) found no differences in amino acid digestibility of peas (a moderate-protein ingredient at $275 \mathrm{~g} / \mathrm{kg}$ crude protein) determined using either the direct or difference methods. The underestimation of AIDC by the direct method may be due to two reasons. Firstly, it has been shown (Angkanaporn et al., 1997; Fan et al., 1994; Ravindran et al., 2009) that apparent ileal amino acid digestibilities are dependent on the protein and amino acid concentrations in the assay diet. Due to the low to moderate concentration of amino acids in the test cereals and grain legumes, the amino acid intakes by birds were low. At such low intakes, the apparent digestibility estimates were lower due to the greater proportion of endogenous protein present at the terminal ileum, relative to the undigested protein of dietary origin.

Secondly, in the assay diets used in the current study, an inclusion level of $938 \mathrm{~g} / \mathrm{kg}$ feed was used for the two cereals, $450 \mathrm{~g} / \mathrm{kg}$ for lupins and $720 \mathrm{~g} / \mathrm{kg}$ for peas. The normal levels of inclusion of these ingredients in practical broiler diets are much lower than these inclusions, as in the case of lupins and peas, inclusion levels of 200 to 300 $\mathrm{g} / \mathrm{kg}$ are recommended in well-balanced diets (Farrell et al., 1999; Nalle, 2009). Moreover, for ingredients that contain significant amounts of non-starch polysaccharides (e.g. wheat and lupins), such high inclusion levels would have lowered the apparent digestibility through mechanisms including increased digesta viscosity (Smits and Annison, 1996) and greater endogenous protein secretions (Angkanaporn et al., 1994; Siriwan et al., 1993).

\section{Conclusions}

The application of the direct method measurement resulted in the underestimation of the AIDC of most amino acids in the ingredients tested. Abdollahi et al. (2015) similarly observed that the assay methodology influenced the digestibility of amino acids in palm kernel meal, a poorly digested lower protein ingredient for broilers. In their study, AIDC of amino acids determined by the direct method were distinctly higher than those determined by the difference method. Based on these findings, the difference method was deemed more suitable for the determination of digestible amino acids in ingredients containing low to moderate concentrations of protein. 


\section{Conflict of interest}

The authors declare no conflict of interest.

\section{References}

Abdollahi, M.R., Hosking, B. and Ravindran, V., 2015. Nutrient analysis, metabolisable energy and ileal amino acid digestibility of palm kernel meal for broilers. Animal Feed Science and Technology 206: 119-125.

Angkanaporn, K., Choct, M. and Bryden, W.L., 1994. Effects of wheat pentosans on endogenous amino acid losses in chickens. Journal of the Science of Food and Agriculture 66: 399-404.

Angkanaporn, K., Ravindran, V. and Bryden, W.L., 1997. Influence of caecectomy and dietary protein level on apparent excreta amino acid digestibility in adult cockerels. British Poultry Science 38: 270-276.

Association of Official Analytical Chemists (AOAC) International, 2016. Official methods of analysis, $20^{\text {th }}$ edition. AOAC, Washington, DC, USA.

Bryden, W.L., Li, X., Ravindran, G., Hew, Li. and Ravindran, V. 2009. Ileal digestible amino acid values in feedstuffs for poultry. Report No. RIRDC Project No: PRJ-002827. Rural Industries Research and Development Corporation, Barton, ACT, Australia.

Fan, M.Z. and Sauer, W.C., 1995a. Determination of apparent ileal amino acid digestibility in barley and canola meal for pigs with the direct, difference and regression methods. Journal of Animal Science 73: 2364-2374.

Fan, M.Z. and Sauer, W.C., 1995b. Determination of apparent ileal amino acid digestibility in peas for pigs with the direct, difference and regression methods. Livestock Production Science 44: 61-72.

Fan, M.Z., Sauer, W.C., Hardin, R.T. and Lien, K.A., 1994. Determination of apparent ileal amino acid digestibility in pigs: effect of dietary amino acid level. Journal of Animal Science 72: 2851-2859.

Farrell, D.J., Perez-Maldonado, R.A. and Mannion, P.F., 1999. Optimum inclusion of field peas, faba beans, chick peas and sweet lupins in poultry diets. II. Broiler experiments. British Poultry Science 40: 674-680.

Gatel, F., 1994. Protein quality of legume seeds for non ruminant animals: a literature review. Animal Feed Science and Technology 45: 317-348.

Huang, K.H., Li, X., Ravindran, V. and Bryden, W.L., 2006. Comparison of apparent ileal amino acid digestibility of feed ingredients measured with broilers, layers, and roosters. Poultry Science 85: 625-634.

Huang, K.H., Ravindran, V., Li, X., Ravindran, G. and Bryden, W.L., 2007. Apparent ileal digestibility of amino acids in feed ingredients determined with broilers and layers. Journal of the Science and Food Agriculture 87: 47-53.

Lemme, A., Ravindran, V. and Bryden, W.L., 2004. Ileal digestibility of amino acids in feed ingredients for broiler. World's Poultry Science Journal 60(4): 423-438.
Mateos, G.G., Cámara, L., Fondevila, G. and Lázaro, R.P., 2019. Critical review of the procedures used for estimation of the energy content of diets and ingredients in poultry. Journal of Applied Poultry Research 28: 506-535.

Nalle, C.L., 2009. Nutritional evaluation of grain legumes for poultry. PhD-thesis, Massey University, Palmerston North, New Zealand.

Nalle, C.L., Ravindran, G. and Ravindran, V., 2011a. Nutritional value of peas (Pisum sativum L.) for broilers: apparent metabolisable energy, apparent ileal amino acid digestibility and production performance. Animal Production Science 51: 150-155.

Nalle, C.L., Ravindran, G. and Ravindran, V., 2011b. Nutritional value of narrow-leafed lupin (Lupinus angustifolius) for broilers. British Poultry Science 52: 775-781.

National Research Council (NRC), 2012. Nutrient requirements of swine, $11^{\text {th }}$ edition. National Academy Press, Washington, DC, USA.

Petterson, D.S., Sipsas, S. and Mackintosh, J.B., 1997. The chemical composition and nutritive value of Australian pulse, $2^{\text {nd }}$ edition. Grain Research and Development Corporation, Kingston, ACT, Australia.

Ravindran, V. and Bryden, W.L., 1999. Amino acid availability in poultry-in vitro and in vivo measurements. Australian Journal of Agricultural Research 50: 889-908.

Ravindran, V., Adeola, O., Rodehutscord, M., Kluth, H., Van der Klis, J.D., Van Eerden, E. and Helmbrecht, A., 2017. Determination of ileal digestibility of amino acids in raw materials for broiler chickens results of collaborative studies and assay recommendations. Animal Feed Science and Technology 225: 62-72.

Ravindran, V., Hew, L.I., Ravindran, G. and Bryden, W.L., 2005. Apparent ileal digestibility of amino acids in dietary ingredients for broiler chickens. Animal Science 81: 85-97.

Ravindran, V., Morel, P.C.H., Rutherfurd, S.M. and Thomas, D.V., 2009. Endogenous flow of amino acids in the avian ileum is increased by increasing dietary peptide concentrations. British Journal of Nutrition 101: 822-828.

SAS Institute, 2005. SAS/STAT ${ }^{\oplus}$ user's guide: statistics. Version 6.12. SAS Institute Inc., Cary, NC, USA.

Short, F.J., Gorton, P., Wiseman, J. and Boorman, K.N., 1996. Determination of titanium dioxide added as an inert marker in chicken digestibility studies. Animal Feed Science and Technology 59: 215-221.

Siriwan, P., Bryden, W.L., Mollah, Y. and Annison, E.F., 1993. Measurement of endogenous amino acid losses in poultry. British Poultry Science 34: 939-949.

Smits, C.H.M. and Annison, G., 1996. Non-starch polysaccharides in broiler nutrition-towards a physiologically valid approach to their determination. World's Poultry Science Journal 52: 203-221.

Sweeney, R.A., 1989. Generic combustion method for determination of crude protein in feeds: collaborative study. Journal of the Association of Official Analytical Chemists 72: 770-774. 